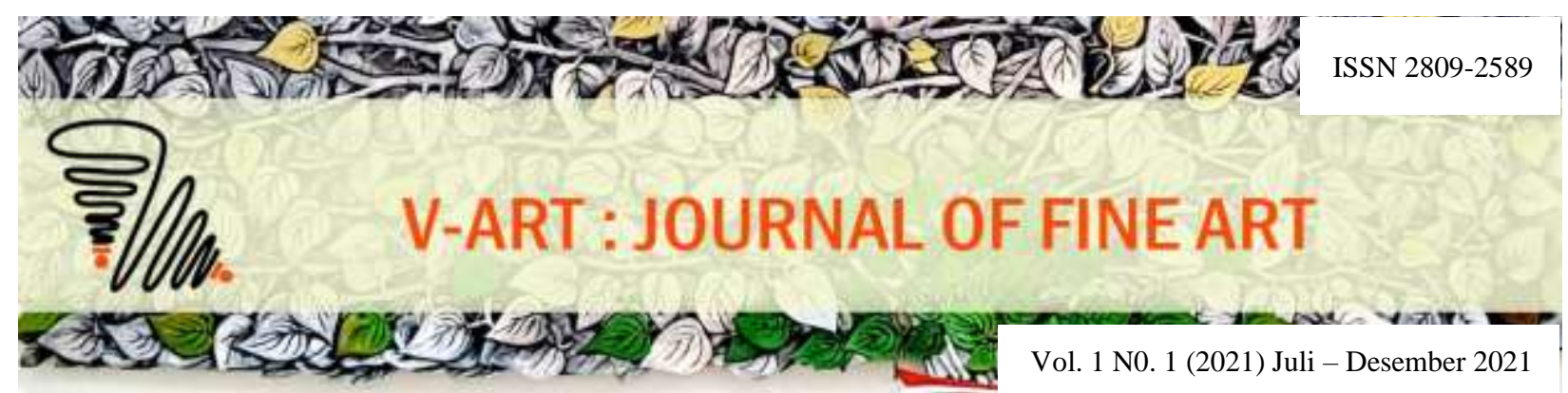

\title{
Karya Patung Abstrak Lisa Widiarti Ditinjau Dari Bentuk Dan Medium
}

\author{
Khairun Nisa ${ }^{1}$, Elvis ${ }^{2}$, dan Armen Nazaruddin ${ }^{3}$ \\ Program Studi Seni Murni, Fakultas Seni Rupa dan Desain \\ Institut Seni Indonesia Padangpanjang \\ Jalan Bahder Johan No. 35, Kelurahan Guguk Malintang, Padangpanjang, 27128 \\ Sumatera Barat, Indonesia \\ Email:khairunnisa8069@gmail.com,elvistoton@gmail.com,dan armenpatung@gmail.com
}

\begin{abstract}
Abstrak
Penelitian ini membahas tentang bentuk dan medium yang digunakan Lisa Widiarti dalam membuat karya patung abstrak. Penelitian ini juga membahas sekilas tentang perjalanan singkat berkesenian Lisa Widiarti. Pembahasan menggunakan metode penelitian kualitatif, yang meliputi: observasi, wawancara dan studi pustaka serta penelitian dilakukan di daerah kota Padang, Sumatera Barat. Berdasarkan hasil penelitian tentang karya patung abstrak Lisa Widiarti, Lisa telah menghasilkan puluhan karya patung abstrak dan hampir setiap tahun selalu mengikuti eventevent pameran. Lisa cenderung menghadirkan objek yang bertemakan kasih sayang, sosial, kehidupan sehari-hari dan keindahan ke dalam karya patungnya yang dibuat dengan bentuk abstrak, dan medium yang digunakan dalam berkarya beragam seperti: resin, batu, kayu, semen, gipsum, logam plat dan bubur kertas. Lisa adalah seorang pematung wanita yang juga menjadi dosen di Universitas Negeri Padang, Lisa tetap mampu bertahan dengan karya patung abstraknya dan menjadi seorang pematung wanita yang ulet, kreatif dan aktif berkarya di Sumatera Barat. Banyak yang bisa dipelajari dan diteliti dari karya patung Lisa Widiarti khususnya karya patung abstrak yang ditinjau dari segi bentuk dan medium. Diharapkan penelitian mengenai karya patung abstrak Lisa Widiarti dapat menjadi acuan, sehingga terbuka peluang bagi peneliti lain untuk meneliti dari sudut pandang keilmuan yang berbeda.
\end{abstract}

Kata Kunci: Patung Abstrak; Lisa Widiarti; Bentuk; Medium.

\begin{abstract}
This study discusses the form and medium used by Lisa Widiarti in making abstract sculptures. This study also briefly discusses Lisa Widiarti's short artistic journey. The discussion uses qualitative research methods, which include: observation, interviews, and literature study as well as research conducted in the city of Padang, West Sumatra. Based on the results of research on Lisa Widiarti's abstract sculpture, Lisa has produced dozens of abstract sculptures and almost every year always participates in exhibition events. Lisa tends to bring objects with the themes of love, social, everyday life, and beauty into her sculptures which are made with abstract shapes, and the mediums used in her work are various such as resin, stone, wood, cement, gypsum, metal plate and slurry. paper. Lisa is a female sculptor who is also a lecturer at Padang State University. Lisa is still able to survive with her abstract sculptures and become a resilient, creative, and active female sculptor in West Sumatra. Much can be learned and researched from Lisa Widiarti's sculptures, especially abstract sculptures in terms of form and medium. It is hoped that research on Lisa Widiarti's abstract sculpture can be a reference so that there are opportunities for other researchers to research from a different scientific point of view.
\end{abstract}

Keywords: Abstract Sculpture; Lisa Widiarti; Form; Medium. 


\section{PENDAHULUAN}

Lisa Widiarti merupakan pematung wanita di Sumatera Barat yang aktif dan konsisten menghasilkan karya seni patung, dan juga merupakan satu-satunya dosen seni patung wanita yang mengajar di Jurusan Seni Rupa Fakultas Bahasa dan Seni Universitas Negeri Padang (UNP). Walaupun berprofesi sebagai akademisi Lisa Widiarti tetap mampu aktif menghasilkan karya seni patung, sehingga Lisa menjadi seniman patung wanita di Sumatera Barat. Lisa Widiarti yang akrab dipanggil Lisa merupakan orang Sumatera Barat kelahiran Palembang pada tanggal 21 Desember 1964. Lisa sudah memiliki jiwa seni semenjak kecil dan bakat seni yang dimiliki mengalir dari kedua orang tuanya yang memiliki jiwa seni dan mengenal keseniankesenian tradisi.

Karya patung yang dihasilkan oleh Lisa berorientasi pada bentuk-bentuk abstrak, dan dalam berkarya Lisa menggunakan berbagai macam medium (bahan), di mana dalam pemilihan dan penggunaan medium dalam berkarya sangat berpengaruh kepada teknik, proses dan bentuk akhir dari karya patung yang dihasilkannya. Dalam perjalanannya Lisa telah banyak menghasilkan karya-karya seni patung dan mengikuti beberapa event pameran bersama dengan beberapa seniman patung lainnya, dan pameran yang diikuti di berbagai kota seperti: Jakarta, Bandung, Yogyakarta, Padang dan kota-kota lain di Indonesia. Di samping itu, Lisa juga dikenal sebagai salah satu pelopor berdirinya Asosiasi Pematung Indonesia (API) Sumatera Barat, dan menjadi ketua pengurus dari awal terbentuknya hingga sekarang.

Sebagai seorang wanita yang memilih untuk menjadi seniman patung serta berprofesi sebagai akademisi yang aktif dan konsisten berkarya seni patung bukanlah pilihan yang mudah, apalagi Lisa keturunan orang Minangkabau dengan kultur budaya Islam yang kuat, dan juga pemahaman masyarakat di Sumatera Barat terhadap seni patung yang masih rendah, apalagi dihubungkan dengan adat dan norma-norma yang berpegang teguh pada ajaran Islam, di mana anggapan tentang karya seni patung (realis) bukanlah seni yang baik di tengah-tengah masyarakat, karena masyarakat menganggap karya patung tersebut sebagai berhala. Namun, Lisa tetap mampu bertahan dengan karya patung abstraknya dan menjadi seorang pematung wanita yang ulet dan kreatif. Di samping Lisa yang juga mempunyai tuntutan sebagai seorang akademisi aktif yang saat ini juga kembali melanjutkan pendidikan Strata tiga (S3) di Universitas Negeri
Padang, dan disela kesibukannya tersebut Lisa tetap mampu aktif dan konsisten menghasilkan karya seni patung.

Kehadiran Lisa dalam kancah seni patung di Sumatera Barat sangat berpengaruh dalam memunculkan semangat generasi penikmat seni untuk menggeluti seni patung, hal itu ditunjukkan Lisa lewat pendidikan seni patung yang diajarkannya di Universitas Negeri Padang, serta karya-karya seni patung khususnya karya patung abstrak yang telah dihasilkan sangat menarik ditinjau dari segi bentuk dan berbagai medium yang digunakan. Hal tersebut memicu ketertarikan untuk meneliti karya-karya patung abstrak Lisa Widiarti, dalam hal ini penelitian lebih memfokuskan pada bagaimana bentuk karya patung abstrak yang dihasilkan dan medium apa saja yang digunakan oleh Lisa dalam karya-karyanya. Diisyaratkan penelitian ini akan bertujuan untuk menganalisis bentuk dan mengetahui medium apa saja yang digunakan Lisa pada karya patung abstraknya.

Berkaitan dengan hal tersebut, maka untuk mengungkap bentuk dan medium pada karya patung abstrak Lisa Widiarti digunakan pendapat yang di kemukakan oleh Feldman. Konsep-konsep yang dipakai disesuaikan dengan permasalahan yang akan diteliti. Konsep yang digunakan tersebut yaitu: (1) gaya seni, (2) struktur seni dan (3) interaksi medium dan makna (Feldman, 1967). Semua jenis kesenian, visual atau akustis, baik yang kongkrit maupun yang abstrak, wujud yang ditampilkan dan dapat dinikmati oleh penikmat mengandung dua unsur yang mendasar: bentuk (form) dan struktur atau tatanan (A.A.M. Djelantik, 2001). Dalam pembahasan karya patung abstrak Lisa Widiarti hanya menggunakan struktur seni yang terdiri atas unsur visual di antaranya garis, bidang, warna, tekstur, dan bentuk (form), serta interaksi medium dan makna.

\section{KAJIAN TEORI}

Untuk memahami kepribadian seniman dituntut pengetahuan latar belakang sosio-kultural, di mana tokoh dibesarkan, bagaimana proses pendidikan formal dan informal yang dialami, watak-watak orang yang ada di sekitarnya, memoar, buku harian, suratsurat dan lain sebagainya (Kartodirjo, 1993). Dalam mengungkap bentuk dan medium pada karya patung abstrak Lisa Widiarti digunakan beberapa pendapat, dan dalam menganalisanya digunakan pendapat yang di kemukakan Feldman. Konsep-konsep yang dipakai disesuaikan dengan permasalahan yang akan diteliti. Konsep yang digunakan tersebut yaitu: (1) gaya seni, 
(2) struktur seni, dan (3) interaksi medium dan makna (Feldman, 1967).

Pembahasan karya patung abstrak Lisa Widiarti menggunakan struktur seni yang terdiri atas unsur visual di antaranya: garis, bidang, warna, tekstur, dan bentuk (form), serta interaksi medium dan makna. Pemilihan unsur tersebut dikarenakan pada karya patung abstrak Lisa Widiarti memiliki kekhasan pada bentuknya, garis, bidang, warna, tekstur, serta medium pembuatan karyanya yang beragam. Untuk menghasilkan karya seni patung dalam upaya pencarian bentuk dan makna yang dimaksudkan oleh seniman, bahwa seniman harus memiliki kecakapan tentang penguasaan bahan itu sendiri. Kecakapan yang dimaksud dapat dipahami sebagai pengetahuan tentang apa yang dapat dilakukan melalui medium dan kemampuan untuk mengerjakannya. Yang terpenting adalah kesadaran mengenai kesesuaian hasil akhir dengan apa yang akan diekspresikan, yakni kualitas interaksi antara medium dengan makna. Bagaimana medium mempengaruhi apa yang diekspresikan, dan sebaliknya bagaimana isi ekspresif mempengaruhi pemanfaatan medium (Feldman, 1967). Karya-karya yang bersifat abstraksi, yaitu karya-karya yang mengetengahkan objek-objek hasil proses distorsi (mengubah bentuk) dari bentuk-bentuk yang ada di alam, kemudian melahirkan konsepsi kemurnian dari gagasan para seniman, yang di sini berarti penyederhanaan bentuk (Nurjaman, 2010).

\section{METODE PENELITIAN}

\section{Teknik Pengumpulan Data}

Data kualitatif untuk penelitian seni rupa juga bisa didapatkan dari sumber tertulis, sumber lisan, artefak, peninggalan sejarah, serta sumber-sumber rekaman. Teknik pengumpulan data dilakukan melalui observasi pada karya, studi kepustakaan, studi dokumentasi, dan studi lapangan (Soedarsono, 1999: 192). Data yang dibutuhkan dalam penelitian ini dikumpulkan melalui:

\section{a. Studi Kepustakaan}

Studi kepustakaan baik data primer maupun data sekunder (untuk melengkapi atau memperkuat data primer). Data primer autentik atau data langsung dari tangan pertama tentang masalah yang diungkapkan. Ditelusuri dengan metode kepustakaan, yaitu pelacakan sumber melalui buku-buku, arsip, dokumen, koran, majalah, manuskrip, teks-teks sastra, katalog dan sejenisnya yang relevan dengan permasalahan yang dikaji tentang karya patung abstrak Lisa Widiarti.

\section{b. Studi Lapangan}

Sehubungan dengan pengumpulan data dan selain dari studi pustaka juga ada studi lapangan, maka dilakukan kegiatan dalam bentuk sebagai berikut:

\section{1). Observasi}

Metode observasi dilakukan untuk menggali data kebentukan atau data yang bersifat tekstual melalui pengamatan langsung ke tempat kediaman atau studio Lisa Widiarti. Observasi yang dilakukan bertujuan untuk mengklasifikasi data yang didapatkan, serta guna untuk mendapatkan sudut pandang yang kuat dalam meneliti karya patung abstrak Lisa Widiarti. Observasi suatu aktivitas sempit, yakni memperhatikan sesuatu dengan menggunakan mata. Alat bantu yang dibutuhkan dalam melakukan observasi seperti, kamera, alat tulis, tape recorder dan lain-lain (Arikunto, 2006: 156). Dalam melakukan observasi di kediaman Lisa, alat bantu yang digunakan adalah alat tulis dan kamera handphone yang berfungsi untuk pengambilan foto atau video dokumentasi, serta rekaman suara.

\section{2). Wawancara}

Wawancara adalah percakapan dengan maksud tertentu. Percakapan dilakukan oleh dua pihak yaitu pewawancara yang mengajukan pertanyaan dan terwawancara yang memberikan jawaban atas pertanyaan itu. Maksudnya adalah mengadakan komunikasi secara langsung antara peneliti dengan yang diteliti untuk mendapatkan keteranganketerangan atau data-data yang diperoleh secara akurat (Moleong, Lexy, 2012). Wawancara dilakukan secara mendalam atau bebas terpimpin. Instrumen yang digunakan selain peneliti sendiri adalah kamera digital, kamera handphone dan alat rekam sebagai pedoman wawancara dalam bentuk pertanyaanpertanyaan secara garis besar yang dikembangkan pada saat wawancara. Wawancara juga dilakukan dengan beberapa informan lain seperti keluarganya, teman seprofesi, seniman, budayawan dan lain-lain. Hal ini berguna untuk mengetahui mengenai karya patung abstrak Lisa Widiarti, profil dan konsep Lisa Widiarti, kiprah dalam berkeseniannya, serta pengalaman berkesenian Lisa Widiarti.

\section{Pengolahan Data}

Proses pengolahan data dalam penelitian ini meliputi berbagai tahapan. Pertama identifikasi data, mengumpulkan data verbal maupun data visual, baik yang diperoleh melalui studi pustaka, observasi maupun wawancara, dilanjutkan dengan tahapan kedua, klasifikasi data yaitu memilih atau mengelompokkan data penelitian yang telah diidentifikasi sesuai dengan jenis dan sifat data. Seperti data primer, data yang diperoleh dari hasil 
wawancara dan juga data sekunder yaitu data yang didapatkan dari sumber tertulis, baik tentang patung, maupun tentang hal lain yang berkaitan dengan permasalahan penelitian.

Selanjutnya tahap ketiga adalah seleksi data, yaitu menyisihkan data yang kurang relevan dan tidak berkontribusi atas kebutuhan data pada pokok bahasan. Tahapan keempat dilakukan analisis data sesuai dengan teori-teori yang sudah ditetapkan sebelumnya, baik menggunakan analisis tekstual maupun kontekstual yang kemudian diungkapkan dalam bentuk karya tulis. Analisis data adalah proses mengorganisasikan dan mengurutkan data ke dalam pola, kategori, dan satuan uraian dasar sehingga dapat ditemukan tema dan dapat dirumuskan hipotesis kerja seperti yang disarankan olah data (Moleong, Lexy, 2012: 280).

\section{Populasi dan Sampel \\ a. Populasi}

Populasi terdiri atas sekumpulan objek yang menjadi pusat perhatian, dari padanya terkandung informasi yang ingin diketahui. Populasi adalah seluruh data yang menjadi perhatian peneliti dalam ruang lingkup dan waktu yang ditentukan (Sukardi, 2003: 53). Adapun yang menjadi populasi dalam penelitian ini adalah keseluruhan dari karya-karya patung abstrak yang dihasilkan oleh Lisa Widiarti, yang berjumlah 40 lebih karya berdasarkan dari data yang ditemukan. Dengan keseluruhan bentuk karya patung abstrak seperti yang bertemakan kasih sayang, sosial, kehidupan sehari-hari dan keindahan, serta medium yang digunakan pada karyanya yang beragam seperti; resin, batu, kayu, semen, gipsum, logam plat dan bubur kertas. Penentuan populasi sangat membantu untuk memilih sampel-sampel sebagai penguatan keabsahan hasil penelitian. Menentukan populasi dan pengambilan sampel dalam penelitian ini, maka dikumpulkan semaksimal mungkin data-data meskipun dalam bentuk foto atau foto reproduksi.

b. Sampel

Dari populasi yang telah tersedia, maka diambil beberapa karya patung abstrak yang dijadikan sebagai sampel yang akan dibahas mewakili keseluruhannya. Untuk memperkuat hal tersebut Nawawi (1990: 157) menjelaskan bahwa, pengambilan sampel ini tidak didasarkan jumlah, tetapi sampel yang diambil disesuaikan dengan kriteria tertentu yang ditetapkan berdasarkan tujuan penelitian. Teknik pengambilan sampel yang dimaksudkan ialah pengambilan yang dilakukan secara acak tidak dengan runtutan tahun. Hal itu ditujukan terhadap karya patung abstrak Lisa
Widiarti yang telah diklasifikasikan populasinya sesuai kriteria bentuk dan medium karya tersebut. Karya-karya patung abstrak Lisa Widiarti yang dijadikan sampel didasarkan kepada bentuk-bentuk apa saja yang divisualkan Lisa dalam berkarya berjumlah sembilan macam, dan dari ke sembilan karya yang dihadirkan juga dibahas tentang mediummedium apa saja yang digunakan Lisa dalam karya tersebut, di mana masing-masing medium diwakili oleh satu hingga dua karya.

\section{HASIL DAN PEMBAHASAN}

\section{A. Perjalanan Berkesenian Lisa Widiarti}

Lisa Widiarti merupakan satu-satunya pematung wanita di Sumatera Barat yang aktif dan konsisten menghasilkan karya seni patung. Lisa sudah memiliki jiwa atau bakat seni semenjak kecil dan demi mengasah bakatnya dalam bidang seni rupa, Lisa melanjutkan pendidikannya ke Sekolah Menengah Seni Rupa (SMSR) Padang dan memilih minat patung. Setelah satu semester berjalan Lisa mulai mencintai dan merasakan enaknya membuat karya seni patung, dan sejak itu Lisa mulai aktif menghasilkan karya seni patung hingga sekarang.

Setelah menamatkan pendidikan di SMSR Padang tahun 1985, Lisa melanjutkan pendidikan ke jenjang perkuliahan di Institut Teknologi Bandung (ITB) dan kembali mengambil jurusan seni patung. Selama menempuh pendidikan S1 di ITB kemampuan Lisa dalam berkarya semakin meningkat dan keseluruhan karya patung yang dihasilkan Lisa saat menempuh perkuliahan di ITB bentuknya sudah lepas dari bentuk realis, karena karya-karya patung yang dihasilkannya sudah mengarah kepada bentuk patung abstrak. Pengetahuan Lisa tentang seni rupa khususnya seni patung tidak hanya didapatkannya di bangku perkuliahan, namun banyak dari pengalamannya yang sering ikut serta dalam proyek-proyek patung bersama dengan dosen-dosennya, dan Lisa menyelesaikan perkuliahannya selama enam tahun. Setelah menamatkan pendidikannya S1, Lisa disarankan orang tuanya untuk pulang ke kampung halaman dan pada tahun 1996 Lisa akhirnya mengikuti saran orang tuanya untuk pulang kampung dan bekerja sebagai dosen di IKIP Padang. Kemudian pada tahun 1998 Lisa kembali melanjutkan pendidikannya ke jenjang Strata dua (S2) di ITB dan masih mengambil jurusan seni rupa dengan minat patung.

Selama menjadi dosen Lisa tetap mampu untuk aktif berkarya, namun karena keterbatasan waktu dan profesinya sebagai akademisi, Lisa menghasilkan 
karya patung dalam setahun setidaknya dua atau tiga buah karya, paling tidak satu karya. Dalam berkarya Lisa tidak mengikat dirinya dengan konsep-konsep tertentu, konsep yang digunakan Lisa di antaranya seperti konsep tentang kasih sayang, apa yang ada sekitar lingkungan dan sesuai dengan tuntutan yang harus diajarkan di studio kepada mahasiswanya, serta konsep-konsep lainnya.

Karya Lisa termasuk karya yang dijadikan rujukan, bukan hanya di bidang seni patung namun juga di bidang seni murni secara umum yakni grafis dan lukis serta dalam bidang Desain Komunikasi Visual. Hal tersebut karena konsep yang diangkat Lisa dalam berkarya pada umumnya adalah konsep yang aktual atau berangkat dari peristiwa, fenomena dan perasaan yang dialami atau dirasakan oleh Lisa sendiri. Lisa adalah seniman yang peduli terhadap perkembangan seni rupa secara keseluruhan khususnya fokus pada perkembangan seni patung. Medium yang digunakan Lisa dalam berkarya sangat berpengaruh terhadap bentuk karyanya, dan medium tersebut menjadi semacam kekuatan baik dari segi fisik maupun kualitas karyanya dan menjadi karakter tersendiri bagi Lisa. Lisa juga diakui oleh seniman-seniman yang telah mempunyai jam terbang maupun senimanseniman muda termasuk anak-anak didiknya, karena Lisa memberikan semacam spirit terhadap karyakarya yang dihasilkannya dan hal tersebut cukup memberikan kontribusi terhadap perkembangan ilmu pendidikan.

Lisa telah banyak menghasilkan karya-karya seni patung serta mengikuti berbagai event-event pameran baik tingkat daerah dan provinsi, maupun tingkat nasional seperti: Padang, Jambi, Kerinci, Jakarta, Bandung, Yogyakarta dan kota-kota lain di Indonesia. Karya-karya yang dihadirkan Lisa pada umumnya bertemakan kasih sayang, sosial, kehidupan seharihari dan keindahan. Karya-karya yang dihasilkan oleh Lisa semenjak kuliah hingga sekarang menjadi dosen masih berorientasi kepada bentuk khususnya karya patung dengan bentuk abstrak, seperti bentuk abstrak organis, abstrak geometris dan gabungan antara abstrak organis dengan abstrak geometris.

Setelah menamatkan pendidikan S2, Lisa berdiskusi dengan dosennya G. Sidharta yang menjabat sebagai ketua Asosiasi Pematung Indonesia (API) Pusat mengenai bagaimana perkembangan seni patung di Sumatera Barat, dan setelah berdiskusi dibentuklah Asosiasi Pematung Indonesia (API) Sumatera Barat pada tahun 2005, di mana Lisa sebagai salah satu pelopor berdirinya sekaligus sebagai ketua API Sumatera Barat hingga sekarang. Pada tahun 2017 karena saran dari teman-teman dosennya, Lisa kembali melanjutkan pendidikan ke jenjang Strata tiga (S3) di Universitas Negeri Padang (UNP) dan tetap memilih jurusan pendidikan seni rupa (seni patung), hal ini berguna untuk memperdalam ilmunya lebih lagi dan menambah skill mengajarnya sebagai akademisi atau dosen patung di Jurusan Seni Rupa FBS Universitas Negeri Padang.

Mencermati perjalanan berkesenian Lisa Widiarti yang dalam berkarya tidak mengikat dirinya pada satu konsep, tema, gaya, serta bentuk tertentu, begitu juga dengan teknik yang digunakannya dalam berkarya tidak hanya satu atau dua teknik saja, serta medium yang digunakan dalam karyanya yang beragam. Kehadiran Lisa Widiarti sebagai pematung wanita yang aktif berkarya di Sumatera Barat, bahkan Indonesia tentu memberi nilai positif terhadap bakal atau penerus seniman patung wanita. Hal ini sangat memotivasi generasi muda yang ingin berkecimpung dalam dunia seni patung. Hingga sekarang Lisa merupakan satu-satunya wanita yang aktif dan konsisten berkarya patung di Sumatera Barat yang juga berprofesi sebagai staf dosen atau akademisi di Jurusan Seni Rupa FBS Universitas Negeri Padang. Selain aktif menghasilkan karya seni patung dan disela kesibukannya sebagai seorang akademisi, Lisa juga aktif menulis karya tulis seperti: buku, bahan ajar, artikel, jurnal seni dan desain, penelitian tindakan kelas, serta perangkat pembelajaran tentang seni patung dan seni rupa lain yang membantu dalam proses berkesenian dan proses mengajarnya.

\section{B. Bentuk-bentuk Karya Patung Abstrak Lisa Widiarti}

\section{Bentuk Abstrak Organis}

Bentuk abstrak organis diwujudkan dari pengabstraksian atau penyederhanaan bentuk-bentuk alam seperti: manusia, binatang dan tumbuhan (Lisa Widiarti dalam buku Seni Patung Dasar, 2012). Berikut salah satu karya patung abstrak Lisa Widiarti dengan bentuk abstrak organis: 


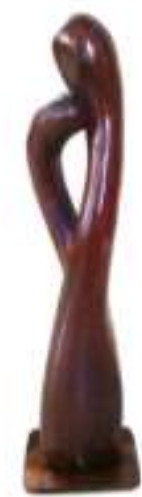

Gambar 1. Lisa Widiarti, "Affection”, $13 \mathrm{~cm} \times 16 \mathrm{~cm} \times 77$ cm, Kayu Jati, Carving, 2005 (Reproduksi: Khairun Nisa, 2018)

Pada karya patung abstrak yang berjudul "Affection" ini berawal dari visualisasi atau pengabstraksian bentuk figur manusia. Karya ini digarap menggunakan bahan kayu jati dengan tekstur karya yang halus serta bidang karya yang lengkung membulat dan memanjang menipis membentuk sudut yang tumpul, serta teknik yang digunakan yakni teknik carving.

Warna yang digunakan pada karya yakni warna cokelat yang kemudian diberi cat pernis. Sesuai dengan judul karya "Affection" ini terinspirasi dari konsep kasih sayang. Karya ini memvisualkan pengabstraksian bentuk dari dua figur yang saling mengasihi dan menyayangi, terlihat dari kedua figur yang saling berangkulan atau berpelukan. Garis lengkung pada karya dan bidangnya yang lengkung membulat menambah kesan kasih sayang yang tulus tak terbatas, serta pemilihan bahan dengan kayu jati juga memberi kesan betapa kuatnya efek atau dampak dari dua figur yang saling mengasihi dan menyayangi.

\section{b. Bentuk Abstrak Geometris}

Bentuk abstrak geometris diwujudkan dari pengabstraksian atau penyederhanaan bentuk geometris seperti: segi tiga, segi empat, lingkaran, limas, kerucut dan bentuk-bentuk geometris lainnya (Widiarti, 2012). Berikut salah satu karya patung abstrak Lisa Widiarti dengan bentuk abstrak geometris:

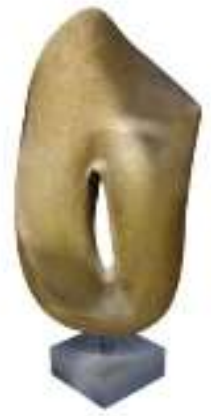

Gambar 2. Lisa Widiarti, "Female", $30 \mathrm{~cm}$ x $50 \mathrm{~cm}$ x $80 \mathrm{~cm}$, Bubur Kertas, Modelling dan Construction, 2015 (Reproduksi: Khairun Nisa, 2018)
Pada karya patung abstrak yang berjudul "Female" ini berawal dari visualisasi figur wanita dengan segala kewanitaannya yang telah diabstraksikan bentuknya menyerupai kelamin wanita (yang mewakili). Karya ini digarap dengan bahan bubur kertas, dan penggarapan karya menggunakan teknik modelling dan construction. Karya ini digarap dengan tekstur kesat ditambah dengan aksen garis yang lengkung tak beraturan, serta bidang karya yang lengkung dan bidang lengkung membentuk sudut tumpul, dan warna yang digunakan pada karya yakni warna emas (gold).

Karya patung abstrak dengan judul "Female" ini, terinspirasi dari visual alat kelamin wanita yang mewakili konsep wanita dengan kewanitaannya. Karya ini berangkat dari ide atau pemikiran tentang eksistensi seorang wanita dengan segala kewanitaannya. Karya ini adalah gambaran dari figur seorang wanita, di mana dalam islam wanita adalah makhluk yang mulia. Bidang karya yang lengkung dan sudut yang tumpul (tak bersudut) memvisualkan sifat wanita yang lembut, elegan dan memiliki rasa kasih sayang yang tak terhingga. Wanita adalah makhluk yang mulia dan istimewa, salah satunya karena dari rahim wanita lahir generasi penerus masa depan dan memiliki peran yang besar dalam kehidupan. Dari hal tersebutlah yang kemudian diabstraksikan atau divisualkan oleh Lisa ke dalam bentuk karya patung abstraknya. Warna emas pada karya menambah kesan layaknya matahari yang memiliki kekuatan untuk menambah kehangatan yang dapat mempengaruhi segala hal yang ada di sekitarnya, dan juga memberi kesan kemuliaan.

\section{c. Bentuk Gabungan Abstrak Organis Dengan Abstrak Geometris}

Bentuk karya patung abstrak ini diwujudkan dari pengabstraksian atau penyederhanaan bentuk-bentuk alam dengan bentuk-bentuk geometris (Widiarti, 2012). Berikut salah satu karya patung abstrak Lisa Widiarti dengan bentuk gabungan antara abstrak organis dengan abstrak geometris:

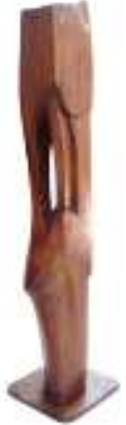

Gambar 3. Lisa Widiarti, "Torso II", $14 \mathrm{~cm}$ x $25 \mathrm{~cm}$ x $90 \mathrm{~cm}$, Kayu Jati, Carving, 2015, (Reproduksi: Khairun Nisa, 2018) 
Pada karya patung abstrak yang berjudul "Torso II" ini menampilkan pengabstraksian bentuk torso figur wanita. Karya ini digarap menggunakan bahan kayu jati dengan teknik carving dan karya ini digarap dengan tekstur halus, serta bidang karyanya yang lengkung. Garis yang digunakan dalam penggarapan karya yakni campuran dari garis lengkung yang membentuk sudut tumpul, garis lurus diagonal yang membentuk sudut tajam dan garis lurus vertikal, namun pada karya lebih dominan menggunakan garis lengkung.

Warna yang digunakan pada karya yakni warna asli kayu jati itu sendiri yang kemudian diberi cat pernis. Karya dengan judul "Torso II" ini, terinspirasi dari bentuk torso figur wanita dengan proporsi tubuh yang ideal. Hal tersebut dapat terlihat dari pengabstraksian bentuk karya yang menggambarkan torso atau anatomi figur wanita, di mana karakter tubuh wanita memiliki pinggul yang lebar dan bahu yang sempit. Dapat dilihat dari garisnya yang lengkung, garis lurus diagonal dan vertikal serta bidangnya yang lengkung, hal ini memvisualkan bentuk tubuh wanita yang ideal dan juga memberi kesan mengenai sifat wanita yang walaupun keras namun tetap lemah lembut dan penuh semangat, namun juga bisa labil. Bagian bawah karya pada bidang lengkung yang sedikit menonjol memvisualkan kelamin wanita. Pemilihan bahan kayu jati yang keras dan kuat memberi kesan fisik seorang wanita kuat namun tetap bersifat lemah lembut dan tenang. Warna asli kayu pada karya yakni warna cokelat tua yang mana warna ini memberi kesan wanita yang hangat dan penuh dengan kasih sayang.

\section{Medium-medium yang digunakan Lisa Widiarti dalam berkarya \\ 1. Medium Resin}

Alasan penggunaan medium ini dilihat dari pertimbangan kualitas fisik (serat, kelenturan dan kekuatan) dan pertimbangan gagasannya (karya-karya yang secara gagasan menggunakan bahan tersebut). Medium resin ini memiliki serat yang halus, menduplikasi ketepatan bentuk dari modelnya mudah dan kualitas fisik mediumnya yang tahan terhadap bahan kimia, serta jika karya patung tersebut pecah bisa diperbaiki kembali dengan cara didempul. Namun penggarapan atau proses pengerjaan karya dengan menggunakan medium ini lebih panjang atau banyak memakan waktu dari pada medium lainnya (dari awal hingga finishing). Dari segi biaya pun karya dengan medium ini lebih mahal dari pada medium lainnya, apalagi karya tersebut berukuran besar dan dicetak padat. Karya patung dengan medium resin ini bisa dipajang di dalam dan di luar ruangan, namun karya patung Lisa dengan medium ini lebih cenderung dipajang di dalam ruangan.

\section{b. Medium Batu}

Alasan penggunaan medium ini dilihat dari pertimbangan kualitas fisik (tekstur, kepadatan dan kekuatan) dan penempatan karya patungnya (ketahanan terhadap cuaca untuk patung yang dipajang di luar ruangan). Medium batu dengan kualitas fisik yang bagus menjadikan karya patung tersebut awet atau lebih tahan lama terhadap kondisi cuaca walaupun terletak di luar ruangan. Namun dalam penggarapan karya dengan medium batu ini memerlukan konsepsi hasil yang ditentukan dengan baik sebelum melakukan proses penggarapan dan harus menguasai teknik yang sesuai dengan medium seperti menggunakan teknik carving (pahat), karena jika tidak sepenuhnya menguasai konsep dan tekniknya maka bentuk yang diharapkan tidak dapat tercapai dengan baik dan beberapa bagian dari medium tersebut jadi terbuang banyak. Karya patung dengan medium batu ini bisa dipajang di dalam dan di luar ruangan, namun karya patung Lisa dengan medium ini lebih cenderung dipajang di luar ruangan.

\section{c. Medium Kayu}

Alasan penggunaan medium ini dilihat dari pertimbangan kualitas fisik (tekstur, serat, kepadatan, dan kekuatan) dan pertimbangan visualnya (bentuk permukaan). Medium kayu sama halnya dengan medium batu memiliki kualitas fisik yang bagus, dan permukaan dari medium kayu ini juga bagus. Penggarapan karya patung dengan medium kayu ini bisa digarap dengan banyak cara atau teknik seperti teknik carving, digergaji, atau dipotong-potong, namun untuk karya patung yang dipajang di luar ruangan jika dibandingkan kualitas fisiknya, medium batu lebih awet atau tahan lama dari pada medium kayu terhadap kondisi cuaca, dan hal tersebut juga tergantung kepada kualitas jenis kayu yang dipilih. Karya patung dengan medium kayu ini bisa dipajang di dalam dan di luar ruangan, namun karya patung Lisa dengan medium ini lebih cenderung dipajang di dalam ruangan.

\section{d. Medium Semen}

Alasan penggunaan medium ini dilihat dari pertimbangan kualitas fisik mediumnya (tekstur, kepadatan, dan kekuatan), pertimbangan visual (bentuk permukaan), dan pertimbangan gagasan (karya-karya yang secara gagasan ingin menggunakan bahan tersebut), serta pertimbangan penempatan (ketahanan terhadap cuaca untuk dipajang di luar ruangan). Medium semen ini bisa digarap dengan 
teknik plastering (diplester atau dipoles), teknik casting (cetak), dan teknik carving (pahat). Jika digarap dengan teknik cetak sama halnya dengan medium resin proses berkaryanya akan panjang dari pada menggunakan teknik plastering, namun akan lebih mudah jika digarap dengan teknik carving (pahat) di mana pematung melakukan prinsip pengurangan bahan, dengan menggunakan pahat dan sudip sebagai alat utama. Karya dengan medium ini mudah didapatkan dan lebih ramah lingkungan, medium ini juga cukup kuat dan tahan terhadap kondisi cuaca, serta risiko pengerjaannya lebih rendah sama seperti karya dengan medium kayu dan bubur kertas. Karya patung dengan medium semen ini bisa dipajang di dalam dan di luar ruangan, namun karya patung Lisa dengan medium ini lebih cenderung dipajang di luar ruangan.

\section{e. Medium Gipsum}

Alasan penggunaan medium ini dilihat dari pertimbangan kualitas fisik medium (tekstur, kepadatan, dan kekuatan), pertimbangan visual (bentuk permukaan), dan pertimbangan gagasan (karya-karya yang secara gagasan ingin pemakaian bahan tersebut). Medium gipsum ini bisa digarap dengan teknik plastering (diplester atau dipoles), dan teknik casting (cetak). Penggarapan karya dengan medium gipsum ini cukup mudah, namun harus dikerjakan dengan cepat karena mediumnya cepat kering jika tidak segera dibentuk, dan juga harus mengetahui bagaimana perbandingan air dengan medium gipsum tersebut, jika airnya terlalu banyak hasil karyanya akan lunak dan lebih rapuh, berbeda hal jika perbandingan air lebih sedikit dari pada medium gipsumnya maka karya akan lebih kokoh. Karya patung dengan medium gipsum ini bisa dipajang di dalam dan di luar ruangan, namun karya patung Lisa dengan medium ini lebih cenderung dipajang di dalam ruangan.

\section{f. Medium Logam Plat}

Alasan penggunaan medium ini dilihat dari pertimbangan kualitas fisik medium (tekstur dan kekuatan), pertimbangan visual (warna dan bentuk permukaan), pertimbangan gagasan (karya-karya yang secara gagasan memilih menggunakan bahan tersebut), dan pertimbangan penempatannya (ketahanan terhadap cuaca untuk dipajang di luar ruangan dan kenyamanan terhadap sirkulasi pengunjung). Medium logam plat ini bisa digarap dengan teknik patri, teknik las dan solder. Namun ketika digarap menggunakan teknik las dan solder, jika logam platnya tipis maka bentuk logam plat yang semula bidangnya datar setelah dilas atau disolder bidang logam plat tersebut akan meliuk-liuk saat digabungkan. Jika medium logam plat yang tebal digarap dengan teknik las maka kekuatan pada medium karyanya akan lebih, berbeda halnya jika dengan teknik solder kekuatan mediumnya akan berkurang dan gampang lepas. Karya patung dengan medium logam plat ini bisa dipajang di dalam dan di luar ruangan, namun karya patung Lisa dengan medium ini lebih cenderung dipajang di dalam ruangan.

\section{g. Medium Bubur Kertas}

Alasan penggunaan medium ini dilihat dari pertimbangan kualitas fisik medium (tekstur, kepadatan, dan kekuatan), pertimbangan visual (bentuk permukaan), pertimbangan gagasan (karyakarya yang secara gagasan ingin memakai bahan tersebut), dan pertimbangan penempatannya (ketahanan terhadap cuaca untuk dipajang di luar ruangan). Medium bubur kertas ini jika digunakan dalam penggarapan karya dari segi biayanya tidak semahal medium yang lainnya, namun hal tersebut tidak jadi penghalang untuk nilai atau kualitas karyanya menjadi tinggi dan mahal seperti menggunakan medium yang lain. Proses penggarapan karya dengan menggunakan medium bubur kertas ini tidak lama, dan dari segi kekuatannya untuk karya yang terletak di luar ruangan memang tidak sekuat medium yang lain seperti batu dan kayu, namun jika digarap dengan teknik hingga proses finishing yang sempurna, karya dengan medium bubur kertas ini tetap tahan untuk waktu yang lumayan lama jika dipajang di luar ruangan. Ketika karya dengan medium ini digarap lagi dengan teknik cetak maka hasilnya tidak sedetail saat sebelum dicetak, karena bubur kertasnya tersangkut pada cetakan.

Lisa dalam pemilihan medium untuk karya patungnya memang cenderung memilih menggunakan medium bubur kertas, karena menurutnya jika menggunakan medium ini tidak berbahaya bagi kesehatan, ringan, dan proses penggarapan karyanya tidak lama, serta bentuk atau hasil akhir dari karya patung Lisa dengan medium ini tetap bernilai tinggi dan mahal. Selain itu, medium ini sangat murah dan mudah didapatkan, tidak semahal dan sesulit mendapatkan mediummedium lainnya. Terobosan dalam penggunaan medium bubur kertas ini merupakan sebuah usaha dalam mencari peluang baru dalam hal medium. Karya patung dengan medium bubur kertas ini bisa dipajang di dalam dan di luar ruangan, namun karya patung yang dihasilkan Lisa pada umumnya dipajang di dalam ruangan sehingga tidak masalah untuk menggunakan medium bubur kertas, dan Lisa sudah 
mulai bereksperimen menggunakan medium bubur kertas ini semenjak tahun 2008.

\section{KESIMPULAN DAN SARAN}

\section{Kesimpulan}

Lisa Widiarti merupakan seniman patung wanita di Sumatera Barat yang aktif berkarya, yang juga berprofesi sebagai seorang akademisi aktif di salah satu Perguruan Tinggi Negeri Sumatera Barat, namun dibalik semua itu sudah ratusan karya seni patung yang telah Lisa hasilkan semenjak Lisa mulai menghasilkan karya seni patung, khususnya pada karya patung abstrak sudah puluhan karya yang dihasilkannya hingga sekarang, baik yang bertemakan kasih sayang, sosial, kehidupan sehari-hari, maupun keindahan.

Karya patung abstrak Lisa dominan menghadirkan bentuk abstrak organis, abstrak geometris dan gabungan dari abstrak organis dengan geometris. Dalam pemilihan medium (bahan) pada karya, Lisa menggunakan berbagai macam medium seperti: resin, batu, kayu, semen, gipsum, logam plat dan bubur kertas, namun Lisa tidak menutup dirinya untuk bereksplorasi dan menerapkan bermacam gaya, medium, dan teknik dalam proses berkaryanya.

Lisa satu-satunya pematung wanita yang aktif berkarya seni patung di Sumatera Barat serta mampu bertahan dengan bentuk karya patung abstraknya dan selalu bereksplorasi dengan medium (bahan) yang digunakan dalam berkarya tidaklah mudah, mengingat Kultur budaya di Sumatera Barat dan pemahaman masyarakatnya akan seni patung yang masih setengahsetengah, serta Lisa yang juga berprofesi sebagai akademisi aktif, namun tetap mampu bertahan menjadi pematung wanita yang ulet, kreatif, dan konsisten untuk tetap aktif menghasilkan karya seni patung khususnya karya patung abstrak. Dengan kata lain Lisa Widiarti mampu menjadi salah satu pematung wanita di Sumatera Barat yang diakui, serta karya dan dedikasinya yang dijadikan rujukan dalam bidang pendidikan seni rupa (murni) khususnya dalam bidang seni patung.

\section{Saran}

Lisa Widiarti sepanjang sejarah berkeseniannya telah menunjukkan eksistensinya dalam berkesenian. Banyak hal-hal menarik, baik tentang aspek psikologis, estetis, sosiologis maupun antropologis terkait patung-patungnya dapat dikaji oleh peneliti lain. Karya-karyanya yang estetik dan artistik dapat dijadikan sebagai referensi berkarya bagi seniman patung lainnya.

\section{DAFTAR RUJUKAN}

A.A.M. Djelantik. (2001). Estetika Sebuah pengantar. Bandung: Masyarakat Seni Pertunjukan Indonesia

Arikunto, S. (2006). Prosedur Penelitian Pendekatan Praktis. Jakarta: Rineka Cipta.

Feldman, Edmund, B. (1967). Art As Image and Idea, bagian dua, tiga, terjemahan SP.Gustami. New Jersey: Prentice-Hall.

Kartodirjo, S. (1993). Pendekatan Ilmu Sosial dalam Metodologi Sejarah. Jakarta: PT Gramedia Pustaka Utama.

Moleong, Lexy, J. (2012). Metodologi Penelitian Kualitatif (Edisi Revisi). Bandung: PT Remaja Rosdakarya.

Nurjaman, A. A. (2010). Gerakan Seni Abstrak Indonesia. Yogyakarta: Sinarmassa 68.

Soedarsono, R. M. (1999). Metodologi Penelitian Seni Pertunjukan dan Seni Rupa. Bandung: Masyarakat Seni Pertunjukan Indonesia.

Sukardi. (2003). Metodologi Penelitian; Kompetisi dan Prakteknya. Jakarta: Bumi Aksara.

Widiarti, L. (2012). Seni Patung Dasar. Padang: Jurusan Seni Rupa FBS UNP. 